\title{
Polymorphism of Codon 447 Calcitonin Receptor Gene in North Indians
}

\author{
R.D. Mittal ${ }^{1}$, H.K. Bid ${ }^{1}$ and B. Mittal ${ }^{2}$ \\ Departments of Urology ${ }^{1}$ and Genetics ${ }^{2}$, Sanjay Gandhi Postgraduate Institute of Medical Sciences, \\ Lucknow 226 014, Uttar Pradesh, India
}

KEY WORDS SNP; genetic polymorphism; CTR gene; codon 447 polymorphism

\begin{abstract}
A C/T polymorphism at 1340 nucleotide of the human calcitonin receptor gene is present in the coding region and changes an amino acid at codon 447 from leucine to proline. This genetic variation has been of great interest due to its possible association with polygenic diseases like osteoporosis and calcium oxalate urolithiasis. Allele frequencies of the C/T 1340 polymorphism vary among populations but there is no data regarding its distribution from India. The present study was carried out to determine the Codon 447 polymorphism of CTR gene in 105 normal unrelated individuals from North India. We obtained an allelic frequency of 0.60 and 0.40 for $\mathrm{C}$ and $\mathrm{T}$ allele and percentage of genotypes CC, CT and TT as $24.8 \%, 69.5$. and $5.7 \%$ respectively. Our results suggest that the frequency and distribution of this polymorphism in India is substantially different from other populations and ethnic groups.
\end{abstract}

\section{INTRODUCTION}

Calcitonin is a 32 amino acid peptide hormone produced in the $\mathrm{C}$ cells of mammalian thyroid and plays an important physiological role in calcium homeostasis (Copp 1992). The hormone acts on its target cells via calcitonin receptors (CTR) which belong to class II of G-protein coupled receptors (Chen et al.1997). The human calcitonin receptor is coded by CTR gene on 7q 21.3 has been extensively studied (Lin et al. 1991). It is a complex gene with at least 14 exons. A number of single nucleotide polymorphisms (SNPs) have been identified in the CTR gene and all except two are present in the non-coding regions. A C/T variation at nucleotide 1340 of CTR gene causes a change in amino acid from proline to leucine (Nakamura et al. 1997). This change occurs at 28th amino acid from the $\mathrm{C}$ terminal in the cytoplasmic domain of the protein, which is be-

Address for Correspondence: Dr. R.D. Mittal, Associate Professor, Departments of Urology, Sanjay Gandhi Postgraduate Institute of Medical Sciences, Lucknow 226 014, Uttar Pradesh, India, Fax: 91-522-2668017, Email: rmittal@sgpgi.ac.in, ramamittal@yahoo.com lieved to be involved in G-protein coupling and signal transduction (Rana et al. 2001). The C/T polymorphism in CTR gene can be identified by PCR followed by restriction digestion pattern by Alu 1 restriction enzyme. In recent years, the Alu1 polymorphism has generated lot of interest due to its possible association with polygenic diseases like osteoporosis, calcium oxalate urolithiasis and juvenile idiopathic arthritis. These studies have also pointed out substantial allelic variations of CTR gene in different populations (Chen et al. 2001). For example, T allele coding for leucine allele is more common in Caucasians whereas Japanese and Chinese populations have C nucleotide coding for proline at this position (Nakamura et al.1997; Chen et al. 2001). Similarly, substantial differences also exist in the allelic frequency at this locus in other populations (Masi et al.1998; Taboulet et al.1998; Wolfe III et al. 2003). However, there are no reports of allelic variations from Indian subcontinent where populations are quite different. Therefore, the present study has been carried out to determine the allelic frequency of Codon 447 polymorphism of the CTR gene in North India.

\section{MATERIAL AND METHODS}

\section{Subjects}

Blood samples from 105 unrelated normal healthy individuals, mostly from staff and students of our Institute, was taken in EDTA vials and kept frozen till DNA extraction. The genomic DNA was isolated from peripheral blood by using standard phenol chloroform method (Blin and Stafford 1976).

Polymerase Chain Reaction: PCR analysis of the CTR gene polymorphism was carried out to a total volume of $50 \mathrm{ml}$, containing genomic DNA(100-150ng) ; 2-6 pmol of each primer; $1 \mathrm{X}$ Taq polymerase buffer and 0.25 units of Taq DNA 
Polymerase (Bangalore Genei, India). The primers for the calcitonin receptor gene polymorphism were forward (5' - CTCAGTGATCACGATACTGTG-3') and backward (5' - ATTCAGTGGAACCAGCGTTGG- 3') according to Masi et al (7). PCR amplification was performed in a programmable thermal cycler PTC-100 (Peltier Thermal Cycler, MJ Research). The cycling condition was set as follows: $94^{\circ} \mathrm{C}$ for $5 \mathrm{~min}, 35$ cycles at $95^{\circ} \mathrm{C}$ for $30 \mathrm{~s}, 55^{\circ} \mathrm{C}$ for $30 \mathrm{~s}$ and $72^{\circ} \mathrm{C}$ for $30 \mathrm{~s}$ and one cycle of extension at $72^{\circ} \mathrm{C}$ for $10 \mathrm{~min}$.

\section{Alu1 Restriction Digestion and Electrophoresis}

The PCR product was incubated with 1.5 units of Alu1 (MBI Fermentas) at $37^{\circ} \mathrm{C}$ for $3 \mathrm{hr}$, using the buffer supplied by the manufacturer. The digested product was separated on $9 \%$ polyacrylamide gel electrophoresis (PAGE) and photographed using Alpha Imager (Alpha Corp., USA) documentation system. The sizes were determined using 100-bp ladder (Roche, Germany).

The restriction site is located at the CTG codon encoding the amino acid leucine forming a cuttable site. An Uncuttable site at codon CCG encoding the amino acid proline will remain intact (228 bp). If the product is excisable, two fragments of 120 and 108bp will be present. For digestion, the reaction mixture was incubated overnight at $37^{\circ} \mathrm{C}$ and the product was loaded in a 9\% PAGE. After electrophoresis, the gel was stained with Ethidium bromide.

\section{RESULTS}

Alu1 digestion of different samples produced three patterns: 228bp; 120 and 108 bp; 228, 120 and 108 bp corresponding to $\mathrm{C}, \mathrm{T}$ and $\mathrm{C} / \mathrm{T}$ genotypes (Fig. 1). Accordingly, individuals were classified as $\mathrm{C}$ homozygotes, $\mathrm{T}$ homozygotes and $\mathrm{C} /$ $\mathrm{T}$ heterozygotes respectively. The number and frequency distribution of the three genotypes is shown in Table 1. Out of 105 individuals, 26 (24.8\%) were C/C, 73 (69.5\%) were $\mathrm{C} / \mathrm{T}$ heterozygotes and remaining $6(5.7 \%)$ were $\mathrm{T}$ homozygotes. The allelic frequency of $\mathrm{C}$ and $\mathrm{T}$ alleles was found to be 0.60 and 0.40 respectively and observed heterozygosity was 0.34 in the normal individuals (Table 1).

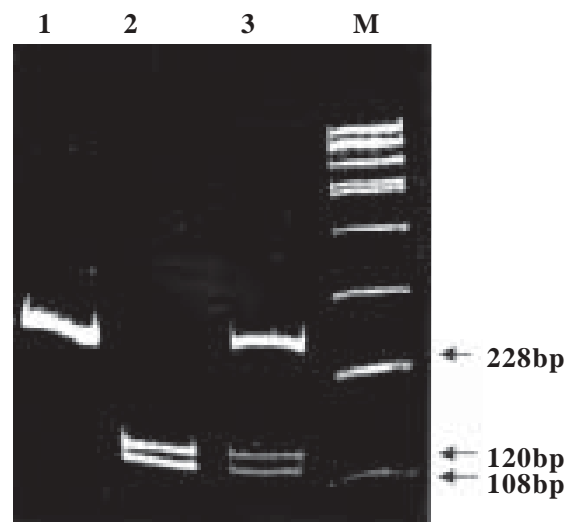

Fig. 1. Schematic diagram and typical patterns of analysis by PCR/Alu-I restriction digestion of the $1377^{\text {th }}$ allelic site in the CTR gene. The allelic variants of the CTR gene are indicated on the top of the gel; if only $\mathrm{C} / \mathrm{C}$ is present the PCR product is not digested by Alu-I enzyme, resulting in 228 bp fragment (CC allelic variant). If only T/T is present the PCR product is digested by Alu-I enzyme in two 120 and 108 bp fragments (TT allelic variant). If $T / C$ is present, half of the PCR product is cut and the other half is uncut resulting in a mixture of 228,120 and 108 -bp fragments ( $\mathrm{T} / \mathrm{C}$ allelic variants)

Table 1: Genotypes and allele frequency distribution of Alu1 polymorphism in North India

\begin{tabular}{lc}
\hline Genotypes & Total No. $(\%)$ \\
\hline $\mathrm{CC}$ & $26(24.8 \%)$ \\
$\mathrm{CT}$ & $73(69.5 \%)$ \\
$\mathrm{T} \mathrm{T}$ & $6(5.7 \%)$ \\
\hline Allele & Frequency \\
\hline $\mathrm{C}$ & 0.60 \\
$\mathrm{~T}$ & 0.40 \\
\hline
\end{tabular}

\section{DISCUSSION}

Identification of SNPs in human genome has great implications in the study of disease susceptibility (Masi et al. 1998; Wolfe111 et al. 2003). The SNP at Codon 447 in the CTR gene has been found to be associated with osteoporosis which causes loss of bone minerals particularly in women after menopause and they become prone to fractures (Masi et al. 1998; Taboulet et al. 1998). It has been reported that individuals with $\mathrm{T} / \mathrm{T}$ allele are more prone to loss of bone mineral density whereas heterozygous state $(\mathrm{T} / \mathrm{C})$ provides protection against osteoporosis. Similarly, T/T has also been implicated by (Chen et al. 2001) in calcium oxalate urolithiasis. The presence of poly- 
Table 2: Codon 447 SNP of human CTR gene in various populations

\begin{tabular}{|c|c|c|c|c|c|c|}
\hline \multirow[t]{2}{*}{ Population } & \multicolumn{2}{|c|}{ Allele frequency } & \multicolumn{3}{|c|}{ Genotypes (\%) } & \multirow[t]{2}{*}{ Reference } \\
\hline & $T$ & $C$ & $T T$ & $T C$ & $C C$ & \\
\hline Japanese & 0.001 & 0.999 & 0.9 & 18.8 & 80.3 & Copp (1992) \\
\hline Chinese & 0.03 & 0.97 & 0 & 5.7 & 94.3 & Masi et al. (1998) \\
\hline Italian & 0.58 & 0.42 & 36.5 & 44.3 & 19.2 & Nakamura et al. (1997) \\
\hline French & 0.68 & 0.32 & 48.8 & 44.7 & 6.5 & Rana et al. (2001) \\
\hline American Caucasians & 0.77 & 0.23 & 59.1 & 36.3 & 4.5 & Taboulet et al. (1998) \\
\hline African Americans & 0.51 & 0.49 & 25.6 & 47.7 & 26.7 & Taboulet et al. (1998) \\
\hline Hispanic & 0.46 & 0.54 & 20.0 & 52.0 & 28.0 & Taboulet et al. (1998) \\
\hline North Indian & 0.40 & 0.60 & 5.7 & 69.5 & 24.8 & Present study \\
\hline
\end{tabular}

morphism of these alleles in various populations suggests that the risk of polygenic diseases associated with CTR variations may also vary in different populations.

In the present study, frequency of $\mathrm{C}$ allele is much higher than $\mathrm{T}$ allele in North Indians and the distribution was found to follow Hardy Weinberg equilibrium. The Caucasians have much higher frequency of $\mathrm{T}$ allele but in African Americans and Hispanic, both alleles are almost equal. The Japanese and Chinese predominantly carry $\mathrm{C}$ allele. Actually, in some studies, $\mathrm{T}$ was absent in normal individuals and its low frequency was observed in patients suffering from urolithiasis (Chen et al. 2001). The major genotype in North Indians was found to be T/C heterozygotes with a low percentage of $\mathrm{T} / \mathrm{T}$ genotypes, which differs considerably from the genotypes observed in different populations (Table 2). In Caucasians, T/T genotype was present in almost $60 \%$ of individuals with T/C and CC accounting for $36 \%$ and $4 \%$ respectively. It may be noted that heterozygous T/C genotypes are usually less than $50 \%$ in Africans and Asians.

\section{CONCLUSION}

Polygenic diseases like osteoporosis, urolithiasis and idiopathic juvenile arthritis are likely to result from combination of genetic variations in several genes. In CTR gene itself, 10 more polymorphisms have been identified but Codon 447 change brings about alteration in a key amino acid, which may have bearing on functional role of the receptor (Woulfe111 et al. 2003).. So far studies of CTR with disease association are rather limited to Italians and Asian populations. As there are large differences in allele frequency and distribution of genotypes of Codon 447 SNP, it would be quite helpful to find out any linkage disequilibrium in individuals from other ethnic groups. In the long run, these studies may help in determining disease susceptibility and clinical management of patients with multifactorial disorders involving calcium metabolism.

\section{REFERENCES}

Blin N and Stafford DW 1976. A general method for isolation of high molecular weight DNA from eukaryotes. Nucleic Acids Res, 3: 2303-2308.

ChenWC, Wu HC, Lu HF et al. 2001. Calcitonin receptor gene polymorphism: A possible genetic marker for patients with calcium oxalate stones. Eur Urol, 39: 716-719.

Chen WJ, Armour S, Way J et al. 1997. Expression, cloning and receptor pharmacology of human calcitonin receptors from MCF-7 cells and their relationship to amyl in receptors. Mol Pharmacol, 52: 1164-1175.

Copp DH 1992. Remembrance: Calcitonin discovery and early development. Endocrinology, 131: 10071008.

Lin HY, Harris TL, Flannery MS et al. 1991. Expression cloning of an adenylate cyclase-coupled calcitonin receptor. Science, 254: 1022-1024

Masi L, Becherini L, Gennari L et al. 1998. Allelic variants of human calcitonin receptor: Distribution and association with bone mass in postmenopausal Italian women. Biochem Biophys Res Commun, 245: 622-626.

Nakamura M, Zhang Z, Shan L et al. 1997. Allelic variants of human calcitonin receptor in the Japanese population. Hum Genet, 99: 38-41.

Rana BK, Shiina T and Insel PA 2001. Genetic variations and polymorphisms of $\mathrm{G}$ protein-coupled receptors: functional and therapeutic implications, Ann Rev Pharmacol Toxicol, 41: 593-624.

Taboulet J, Frenkian M, Frendo JL et al. 1998. Calcitonin receptor polymorphism is associated with a decreased fracture risk in post-menopousal women. Hum Mol Genet, 7: 2129-2133.

Wolfe III LA, Fling ME, Xue Z et al. 2003 In vitro characterization of a human Calcitonin receptor gene polymorphism. Mutation Research, 522: 93105 . 